The Stereochemistry of Electrophilic Addition to 2, 3-Dihydrofuran ${ }^{+}$

\author{
Bunzo Kamo, Koji Ogawa, Minoru Sudo, \\ Mamoru Suzuki and Shijo Furusawa \\ Department of Industrial Chemistry, Faculty of Science and Engineering, \\ Chuo University; Kasuga, Bunkyo-ku, Tokyo 112 Japan
}

The stereochemistry of polar addition of various electrophilic reagents to 2,3-dihydrofuran and its derivatives was studied by NMR.

Chlorination of 2,3-dihydrofuran, 2,3-dihydro-2-methylfuran, 2,3-dihydropyran and benzofuran in toluene at $-78^{\circ} \mathrm{C}$ gave to major products identified as erythro and threo isomers in a ratio of about $60: 40$.

The amount of cis addition was quite sensitive to the change in the solvent, being greater in toluene $(60 \%)$ than in $\mathrm{CH}_{2} \mathrm{Cl}_{2}(30 \%)$. While the addition of electrophilic reagents to $2,3-$ dihydro-5-methylfuran (MDHF) under polar conditions was resulted predominantly to be cis $(80 \%)$, the amount of cis addition showed little differences between $\mathrm{CH}_{2} \mathrm{Cl}_{2}$ and toluene.

Previous assignments for the micro structure of $\alpha$-methyl group of the optical active polymer obtained by stereospecific polymerization of $\mathrm{MDHF}$ in toluene at $-78^{\circ} \mathrm{C}$ were discussed in terms of the informations regarding the type of opening of the double bond in the polar addition reaction of dihydrofurans.

$\dagger$ Polymerization of 2,3-Dihydrofuran Derivatives. IV.

\title{
高密度ポリエチレンの熱分 解
}

(1973 年 3 月 16 日受理)

\author{
村 田 勝 英・牧 野 忠彦*
}

市販の高密度ポリエチレンの熱分解実験を，原料の供給および生成物の取り出しが連続的に行なえる 装置を用いて行ない, 分解速度，分解生成物の性質，組成执よびそれらの分解温度による变化などにつ いて調べた。

その結果，ポリエチレンを熱分解して得られる分解生成物は $\mathrm{H}_{2}$ 特よび $\mathrm{C}_{1} \sim \mathrm{C}_{5}$ の低級炭化水素から なるガス状生成物と $\mathrm{C}_{3} \sim \mathrm{C}_{30}$ の炭化水素からなる液状生成物にわけられ，液状生成物が約 $94.5 \%$ を 占める。ガス状生成物の平均分子量は $35 \sim 37$ で分解温度 $400 \sim 445^{\circ} \mathrm{C}$ ではあまり変化しないが，液状 生成物の平均分子量は 180 から 232 まで変化する。また反応管に滞留している管液は熱分解にお壮る 中間的生成物であるが，常温では固体状で，平均分子量約 1200 の炭化水素であるなどの知見を得た。

また分解速度については分解生成物の留出量から求める分解留出速度と C-C 結合の熱的破断により 生じる二重結合定量して求める二重結合生成速度の両方をいずれも定常状態において測定し, 温度に 対しプロットした。活性化エネルギーは各速度から $47.5,49.4 \mathrm{kcal} / \mathrm{mol}$ が得られた。

\section{1 緒言}

ポリエチレンの熱分解に関する研究は, 1940 年代の終りごろ から分解速度, 分解生成物, 反応機構などについて行なわれてお り, Oakes $5^{1)}$, Wall $ら^{2)}$, Madorsky ${ }^{3}$, Simha $5^{4)}$ による研究

* 三井造船株式会社千葉研究所, 290 市原市八幡海岸通

1) W. G. Oakes, R. B. Richards, J. Chem. Soc., 1949, 2929.

2) L. A. Wall et al., J. Amer. Chem. Soc., 76, 3430(1954).
が報告されている。その結果, ポリエチレンを酸素の存存しない 雾囲気で加熱すると括よそ $290^{\circ} \mathrm{C}$ までは安定であるが，さらに 加熱を行ならと熱分解により低分子量化してワックス状になると ともに二重結合をその中に生成するが， $370^{\circ} \mathrm{C}$ 以下ではガス状生 成物は無視できるほど少ない1)。375〜 400C で熱分解するとポリ

3) S. L. Madorsky et al., J.Res. Nat.Bur. Stand., 42, 499 (1949).

4) R. Simha, L. A. Wall, J. Phys. Chem., 56, 707 (1952). 
エチレンは反応初期に急激に低分子量化し，ガス状生成物となっ て $1 \%$ 減量する間江固有粘度は約 $1 / 50$ 飞低下するが，それ以上

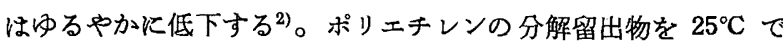
凝縮するものとしないるのにわけると平均 $3.7 \%$ が凝縮しない ガス状生成物で，扣もに低級炭化水素からなるがエチレンの生成 量㤬全分解留出物に対し $0.025 \mathrm{wt} \%$ とすぎず，モノマーの生成 量はポリスチレンなどにくらべ極端化少ないる）。また熱分解の機 構については Simha 5)の一般的機構に基つく, 開始, モノマ 一開裂, 連鎖移動, 停止の 4 種の反応からなる連鎖反応機棈が一 般に認められている。しかしながら従来の研究は数グラム程度の 試料を用い，すへて回分式反応器により行なわれてきたので試料 を連続的に供給し，分解生成物を逨続的に系外飞取り出すことに より定常状態に叔けるポりエホンンの熱分解生成物, 分解速度な どを調べた例はない。本研究では四 3 亿示されるよらな連続式熱

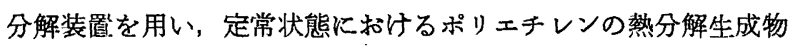
の組成，性質を調べ，さらと熱分解生成物の留出量を測定して求 める分解速度と, 分解のさい生成する二重結合を定量して求める 分解速度の両方を求め比較するとともに括の括のの分解速度から 活性化エネルギーを計算した。

\section{2 実験}

\section{1 原 料}

本実験に用いられた高密度ポリエチンンは市眅のペレット状の もので一般雑貨，コンテナなどの原料となるすのである。本原料 の物性測定叔よび熱分析の結果を以下に述べる。

2.1 .1 物性: 表 1 亿物性の一部之図 1 亿溶融粘度の測定結果 を示す。本実験化用いたポリェチレンの比重は 0.953 の高密度 ポリエチレンでその粘度は多少のせん断速度の違いでは影響を受 けない。物性値の測定方法は分解生成物と一括して 2.2.2 分析 护よび物性測定法の項仁記述する。

Table 1 Properties of high density polyethylene Property

\section{Specific gravity}

Ash content

Conradson carbon

Higher calorific value

Molecular weight $\bar{M}_{\mathrm{n}}$

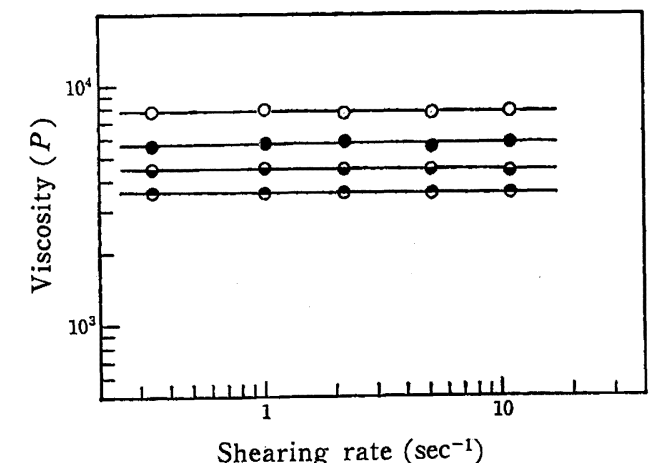

Fig. 1 Viscosity of high density polyethylene Temp. $\left({ }^{\circ} \mathrm{C}\right)$ $\mathrm{O}: 200$, : 250 0.953

0.037 wt $\%$ $0.10 \mathrm{wt} \%$ $11700 \mathrm{cal} / \mathrm{g}$ 8100

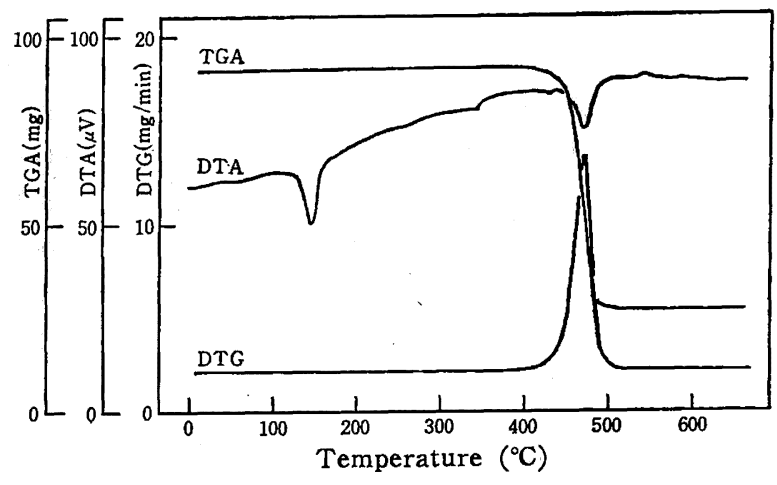

Fig. 2 Thermal analysis curves of high density polyethylene

Heating rate $: 4.4^{\circ} \mathrm{C} / \mathrm{min}$

2.1 .2 熱分析：高分子化合物の熱的性質を簡便に知る方法と して熱分析が行なわれ，ポリエチンンにる適用されているず)。本 実験に拈いても連続式の装置で実験を行なら前に示差熱テンビン を用いて試料の熱分析を行ない,試料の熱的怪質の概要を調べた。

熱分析における測定条件ならびに得られた DTA (示差熱曲線), TGA (熱重量曲線) および DTG（微分熱重量曲線）を図 2 に示 す。図 2 の結果は試料を窒素気流中に扣いて一定速度で加熱した 場合に生じる重量変化, 温度变化を記録したもので, 各温度に対 応する変化はつぎのと拈りである。 $100^{\circ} \mathrm{C}$ まではいずれの曲線に も変化は認められないが， $120^{\circ} \mathrm{C}$ 付近から DTAに吸熱のピーク が始まるのが認められる。この温度付近では TGA, DTGには変 化が認められないので，ポリェチレンの転移または融解に相当す る相変化が起こっていることを示している。TGA および DTG の変化は $380^{\circ} \mathrm{C}$ 付近まで認められないが, $400^{\circ} \mathrm{C}$ を過ぎると重 量减少は顕著になりその速度 (DTG) も急激に增大する。また DTA に拈いてあいちじるしい吸熱変化を生じ，明らかに熱分解 が起こっていることがわかる。重量変化速度は， $470^{\circ} \mathrm{C}$ でピーク に達しているが，これを過ぎると減少し重量はまた一定となる。 ここで TGA，DTGを用い本実験に用いられた高密度ポリエチレ ンの熱分解速度を求めさらに活性化エネルギーを算出する。

ポリエチレンの分解速度はポリエチレンの重量の一次に比例す ると仮定すれば次式が成立する。

$$
-\frac{\mathrm{d} m}{\mathrm{~d} t}=k m
$$

$$
\begin{aligned}
m & : \text { ポリェチレンの重量 } \\
k & : \text { 比速度 }(-\mathrm{d} m / \mathrm{d} t / m) \\
t & : \text { 時間 }
\end{aligned}
$$

図 2 から各温度において TGA から $m$, DTG から $-\mathrm{d} m / \mathrm{d} t$ を読み取り, 比速度 $k$ の值を（1）式を使って求め, Arrhenius プロットすると $390 \sim 450^{\circ} \mathrm{C}$ の範囲で直線が得られた。傾さから 活性化エネルギーを求めると $73 \mathrm{kcal} / \mathrm{mol}$ を得た。他の研究者に よればポリエチレンの熱分解反応に怙ける同様の活性化エネルギ 一は, $68 \mathrm{kcal} / \mathrm{mol}^{5)}, 69 \mathrm{kcal} / \mathrm{mol}^{6)}$ が得られているが, 本研究に 用いられた高密度ポリエチレンの場合これらよりやや大きい結果

5) D. A. Anderson, E. S. Freeman, J. Polym. Sci., 4, 13 (1949).

6) H. H. Horowitz, G. Metzger, Anal. Chem., 35, 1464 (1963). 
となった。

\section{2 熱分解実験}

2.2.1実験装置むよび操作：熱分解に用いられた実験装置を 図 3 に示す。実験装固はU字型をしたパイプからなり、メルター と反応管部にわかれている。試料はペレット状をしており，まず メルター（1）に投入して，ここでバルブ（8）を閉じた状態で $230^{\circ} \mathrm{C}$ まで加熱し，10 時間程度の時間をかけて十分均一な溶融状 態とする。このときメルタ一上部にはつね窒素ガス（13）忞吹 き込み，ポリエチレンが酸化されないよう注意する。メルタ一内 のポリエチレンが十分均一に加熱溶融されてから反応管（2）の 中をへリウムガスで置換し，バルブ（8）を開いて溶融ポリエチ レンを反応管に導く。しかし $230^{\circ} \mathrm{C}$ まで加熱してす本実験に使 われたポリエチレンはまだ非常に粘稠でこのままではほとんど流 入しない。このためメルターに備え付けられたピストン（7）を 使って溶融状態のポリエチレンを押し込み，反応管に供給した。 反応管内はあらかじめ $300^{\circ} \mathrm{C}$ 程度まで予熱して拉くが，ポリエ キレンが供給されてからさらに加熱を行ない，所定の分解温度に たるつよらヒーターを調節する。反応管におけるヒーターは外部 にまきつけられた電熱線であるが，三つにわかれており別々にコ ントロールして反応管内の温度をできるたけ均一にたるつよら工 夫した。温度測定はすべてクロメルーアルメル熱電対により測定 した。反応管内の温度は上部 (14), 中央部 (15), 下部 (16) の 3 点で計測しているが，上部と中央部の温度は分解中つねにほぼ同 一温度を示し, 下部の温度は $\pm 2^{\circ} \mathrm{C}$ 程度の変動があった。この ため中央部の熱電対により測定された温度を以後分解温度と称し， 反応管内の温度を代表させる。

反応管への溶融ポリエチレンの供給は，反応管上部ののぞき空 からつねと管液（反応管内に滞留し，分解しつつあるポリマーを 管液と称する）のレベルを監視し，レベルが反応管上端，ヘッダ 一部分の底面にたすたれるよらにピストンを使って行なった。管 液がさらに分解され，分解温度でガス状となりらるほど低分子量 化すると反応管から留出する。反応管から留出した分解生成物は コンデンサーにより液状生成物（これを分解油と称する）とガス 状生成物（これを分解ガスと称する）にわけられ，液状生成物は

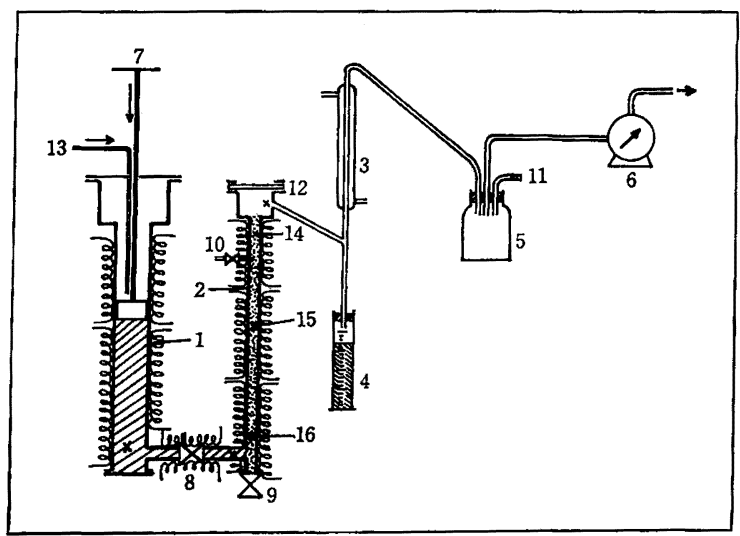

Fig. 3 Experimental apparatus for polymer degration

$1:$ Melter, $2:$ Reactor, $3:$ Condenser, $4:$ Mess cylinder, 5 : Drain pot, $6:$ Gas meter, $7:$ Piston, $8 \sim 10:$ Valves, 11 : Gas sampling, $12:$ Sight glass, $13: \mathrm{N}_{2}$ gas $x$ : Thermocouple
メスシリンダー（4）で受け，一定時間ごとに計測して留出速度 を求め, ガス状生成物はガスメーターにより留出速度を求めた。 分解油のサンプリングは反応管に括ける温度拉よび留出量が十分 一定となった段階で開始し，同時に管液のサンプリングも行ない ヨウ素価を測定した。

2.2.2 分析および物性測定法: 原料の高密度ポリエチレンと これを分解して得られる分解ガス，分解油および管液の分析法な らびに物性測定法を以下に述べる。

\section{1）分解カス}

ガスクロマトグラフィーにより分析した。 $\mathrm{H}_{2}$ 护よび $\mathrm{CH}_{4}$ を活 . 性炭カラムで, $\mathrm{C}_{1} \sim \mathrm{C}_{5}$ の炭化水素をスクアレン付き活性アルミ ナで定量した。

2) 分 解 油

比重 : JIS K 2249 比重浮ヒョウ法による。分解油が室温でワ ックス状である場合には液状となるまで分解油を加温し，その温 度での比重を測定したのち $15 / 4^{\circ} \mathrm{C}$ 比重に換算した。

粘度 : JIS K 2283 キャノンーフェンスケ粘度計により測定し た。

灰分：JIS K 2272 石油製品灰分試験方法による。

残留炭素：JIS K 2270 石油製品残留炭素試験方法による。 引火点 : JIS K 2274 クリーブランド開放式試験器による。 発熱量：JIS K 2279 石油敒品発熱量試験方法による。

ヨウ素価：Wijs 法による。試料を四塩化炭素に溶解し, Wijs 液と $2.5 \%$ 酢酸水銀（II）-水酿酸溶液 $4 \sim 6 \mathrm{ml}$ （酢酸水銀（II） が触媒として働き，反応時間を無添加での 60 分を 3 分に短縮で きる) 7)8）加え約 10 分間暗所に放固したのちヨウ化カリウムを 加え, 残留している塩化ヨウ素をチオ硫酸ナトリウム標準液で滴 定する。

平均分子量 : 凝固点降下法による。溶媒としてベンゼンを用い た。

組成：ガスクロマトグラフィーによる。使用カラムはゴーレイ カラムで, 長さ $90 \mathrm{~m}$, 内径 $0.5 \mathrm{~mm}$, カラム液相 $\mathrm{SE} 30$ シリコ ソゴムラバーを用い, キャリヤーガスはヘリウム $25 \mathrm{ml} / \mathrm{min}$, 分 割比 $1 / 100$, 検出器は FID, カラム温度 $50 \sim 200^{\circ} \mathrm{C}$ プログラム で分析した。

3）管 液

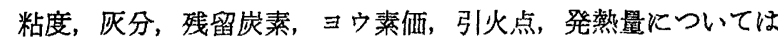
分解油と同じ方法で測定した。

比重 : ピクノメーターにより測定。

平均分子量：エブリオメーター（宝工業製）によりトルエンを 溶媒に用いて沸点上昇法で測定した。

4）高密度ポリエチレン

比重, 灰分, 残留炭紊, 発熱量, 平均分子量は管液と同じ方法 で行なった。

粘度 : 二重円筒型の回転粘度計（岩本製作所製）を用い，温度 およびせん断速度を率化させて湘定した。

\section{3 実験結果と考察}

\section{1 分 解速度}

高分子化合物の熱分解速度は研究者により異なった定義のもの

7) H. D. Hoffman, C. E. Green, Oil \& Soap, 16, 136(1936). 8）小方芳郎, 松山一夫, 工化, 71,100 (1968). 
が使われており，測定方法，測定する量は研究者により適当に工 夫されている。たとえば，試料を一定の熱分解温度にたもち重量

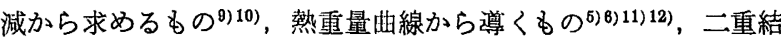
合の生成量から求めるもの ${ }^{118)}$ などであるが，多くは分解速度そ のものよりも活性化エネルギーを問題にすることが多い。またい ずれも実験操作は回分式であり，試料も 1 回に数グラム以下を取 り报らに過ぎず，比較的多睹の試料を用い連続式反応装伹により 分解速度を測定した例は少なく，わずかにポリエチレンのローポ リマーについて行なった著者らの研究18)があるのみである。また 最近プラスチック公害のための廃プラスチックスの熱分解による 処理方法に関する研究14) 16) が報告されているが，分解速度につ いてはいずれるほとんど言及していない。本実験では連続式熱分 解装置を用いて定常状熊汇括ける熱分解速度を求めることを試み， 分解生成物の単位時間, 単位反応管容積あたりの留出量（これを 分解留出速度と称す）および C-C 二重結合を有する不飽和化合 物の単位時間，単位反応管容積あたりの生成量（これを二重結合 生成速度と称す）の両方を求めた。

分解留出速度の測定結果を図 4 亿示す。図 4 では分解温度に対 する分解留出速度をプロットしており，分解温度により分解留出 速度は大きく変化する。しかしながら分解留出速度に占める分解 ガスおよび分解油の割合はほぼ一定で，それぞれ 5.5，94.5\%で， あった。また二重結合生成速度を分解温度に対してプロットした 結果も図 4 亿示す。ここで二重結合は分解ガス，分解油拈よび管 液の中に含まれるが，分解ガス中のオレフィン量はガスクロマト グラフィーによる分析結果から算出し, 分解油中の二重結合はヨ ウ素価を測定して求めた。また管液における二重結合は分解油と 同様にヨウ素価から求められるが，管液のヨウ素価の測定結果を

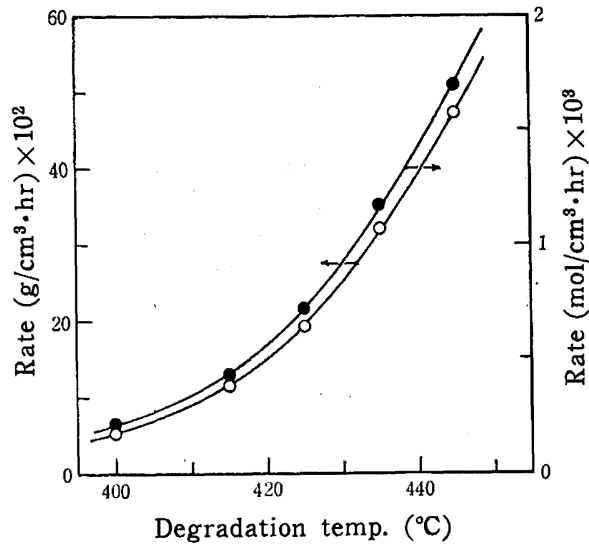

Fig. 4 Rate of thermal degradation

$O$ : Rate of the degradation

: Rate of the formation of double bonds

9) H. H. G. Jellinek, J. Polym. Sci., 4, 13(1949).

10) S. L. Madorsky, S. Straus, J. Res. Nat. Bur. Stand., 53, 361 (1954)

11) C. D. Doyle, J. Appl. Polym. Sci., 5, 285(1961).

12) D. A. Anderson, E. S. Freeman, J. Polym. Sci., 54, 253 (1961).

13）北岡洋治，村田勝英，然料協会誌，50，791(1971).

14）堤 繁，工業材料，20，55(1972).

15) 武末知行, 化学工業, 23, 536(1972).

16）山明 街, 然料協会誌, 51，212(1972).

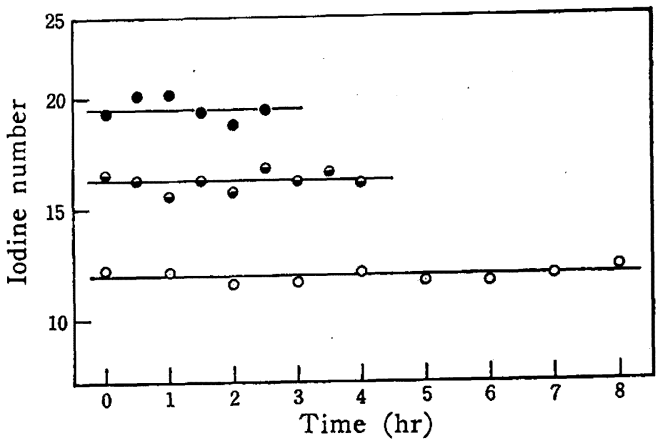

Fig. 5 Iodine number of reactor contents Temp. $\left({ }^{\circ} \mathrm{C}\right)$

$$
\bigcirc: 400, \ominus: 415, \bigcirc: 425
$$

示すと図5のようになりヨウ素価の時間変化は無視することがで きる。すなわち管液の不飽和度 (二重結合) は分解温度によって 異なるが，一定温度ではある濃度に達したのちはほぼ定常をたる ち, 二重結合生成速度への管液に含まれる二重結合量の時間変化 による寄与は無視できると考えられるので，二重結合生成速度に 扣いても分解ガスと分解油のみを対象とした。図 5 に抋いては， 他と同様な結果であるのと眓の繁雑を避けるため $435^{\circ} \mathrm{C}$ およ゙ $445^{\circ} \mathrm{C}$ のデータは省略した。また二重結合生成速度においては, 分解ガス中に含まれて留出する二重結合量の全体に対する割合を 平均すると 14.0\% であった。これは分解留出速度における分解 ガスの割合（重量比）が $5.5 \%$ であったのと比較し，約 2.5 倍 となって拈り分解ガス中により不飽和化合物の生成量が多いこと がわかる。

活性化エネルギーを求めるためには速度式を決めなければなら ないが，熱重量分析に挌ける（1）式のように重量変化のみを考 慮した速度式以外にポリエチレンの熱分解反応の速度式を与え， 活性化エネルギーを求めた例はない。ここでは簡単のため分解留 出速度をそのまま分解速度定数に等しいと拈いて Arrhenius プ ロットすることにより活性化エネルギーを求めると $47.5 \mathrm{kcal} / \mathrm{mol}$ が得られた。また二重結合生成速度についてる同様の活性化エネ ルギーを求めると $49.4 \mathrm{kcal} / \mathrm{mol}$ を得た。

\section{2 分解カス}

分解ガスは水素打よび $\mathrm{C}_{1} \sim \mathrm{C}_{5}$ の炭化水素の混合物であり，分

Table 2 Gas chromatographic analysis of gaseous products

\begin{tabular}{lcr} 
Component & \multicolumn{2}{c}{\begin{tabular}{c} 
Degradation \\
\cline { 2 - 3 }$\left(\begin{array}{c}415^{\circ} \mathrm{C} \\
(\mathrm{mol} \%)\end{array}\right.$
\end{tabular}} \\
\hline $\mathrm{H}_{2}$ & 5.1 & $\begin{array}{c}445^{\circ} \mathrm{C} \\
(\mathrm{mol} \%)\end{array}$ \\
$\mathrm{CH}_{4}$ & 14.2 & 6.0 \\
$\mathrm{C}_{2} \mathrm{H}_{4}$ & 8.0 & 12.0 \\
$\mathrm{C}_{2} \mathrm{H}_{6}$ & 19.4 & 8.9 \\
$\mathrm{C}_{3} \mathrm{H}_{6}$ & 21.4 & 15.4 \\
$\mathrm{C}_{3} \mathrm{H}_{8}$ & 17.2 & 19.6 \\
$1-\mathrm{C}_{4} \mathrm{H}_{8}$ & 4.5 & 17.9 \\
$i-\mathrm{C}_{4} \mathrm{H}_{8}$ & 0.0 & 6.3 \\
$n-\mathrm{C}_{4} \mathrm{H}_{10}$ & 7.6 & 0.1 \\
$i-\mathrm{C}_{4} \mathrm{H}_{10}$ & 0.1 & 10.3 \\
$\mathrm{C}_{5}$ & 2.5 & 0.1 \\
$\bar{M}_{\mathrm{n}}$ & 35.8 & 3.4 \\
${ }_{2}$ & & 37.5
\end{tabular}


解温度による組成の違いは顕著でない。分析値の例を表 2 に示 す。これによれば，分解ガスは平均分子量 35〜37 の低級炭化水 素であり，主なる成分は $\mathrm{H}_{2}, \mathrm{CH}_{4}, \mathrm{C}_{2} \mathrm{H}_{4}, \mathrm{C}_{2} \mathrm{H}_{6}, \mathrm{C}_{3} \mathrm{H}_{6}, \mathrm{C}_{3} \mathrm{H}_{8}$ など である。また分解ガスの全留出物に対する割合は約 $5.5 \%$ で， 分解温度による变化はほとんどみられない。

\section{3 分 解 油}

分解油のガスクロマトグラフィーによる分析結果の代表例を図 6. 7 に示す。これは n-パラフィン, 1-オレフィン拈よ゙これら 以外の成分をアインマーとして処理し，算出した各成分の重量パ 一セントを炭素数に対してプロットしたもので図 6 は $400^{\circ} \mathrm{C}$, 図 7 は $445^{\circ} \mathrm{C}$ の分解油の分析結果である。使用したカラム充テン 阂は非極性であるためチャート上にははぼ沸点順にピークが現わ れるが，炭素数が大きくなるにつれて分離が悪くなり， $\mathrm{C}_{25}$ 以上

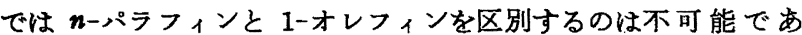
る。図 6，7 Kよればポリエチレンの 分解油は $\mathrm{C}_{3}$ より $\mathrm{C}_{30}$ 付 近の炭素数の炭化水素からなっており, 沸点籁囲は室温以下より 分解温度まであり，非常に幅広い分子量分布をしている。分解温 度 $400^{\circ} \mathrm{C}$ の例（図6）では炭素数 8〜13 にピークがあるが, 分 解温度が上昇するにつれて炭素数 9 付近のピークと炭素数 15 付 近のピークKわかれる傾向（罒 7 ）が認められる。また分解油に

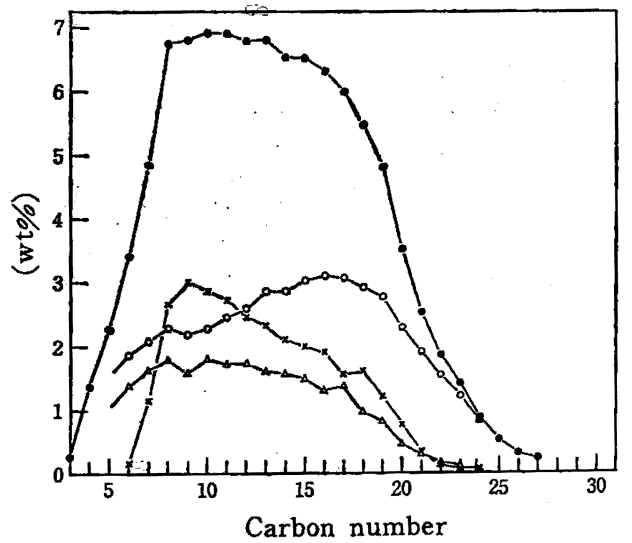

Fig. 6 Gas chromatographic analysis of liquid product at $400^{\circ} \mathrm{C}$

: Total, $\bigcirc: n$-Paraffin, $\times:$ Isomer, $\triangle: 1$-Olefin
特ける $n$-パラフィン, 1-オレフィン, アイソマーの割合は分解 温度により变化し，そのようすを図8に示す。四8 によれば 1オレフィンの割合は分解温度の上昇とともに増加し, $n$-パラフィ ソ, アイソマーは減少の傾向にあることがわかる。

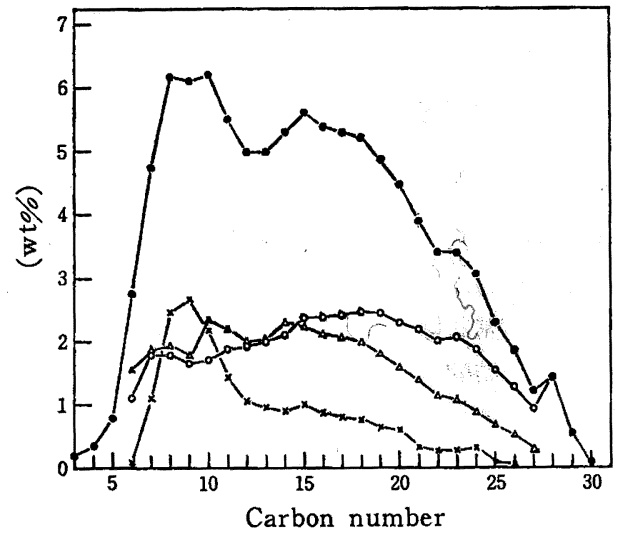

Fig. 7 Gas chromatographic analysis of liquid product at $445^{\circ} \mathrm{C}$

: Total, $O: n$-Paraffin, $X:$ Isomer, $\triangle: 1$-Olefin

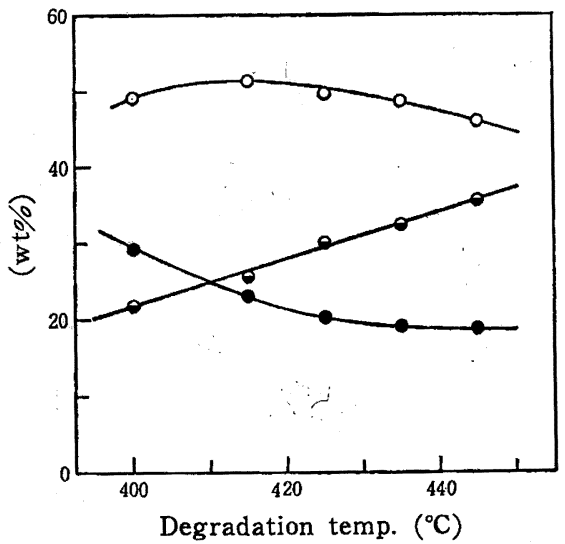

Fig. 8 Rate of $n$-paraffins, 1 -olefins and isomers in liquid products

$\bigcirc: n$-Paraffin, $\ominus: 1$-Olefin, $\bigcirc$ Isomer

Table 3 Properties of liquid products and reactor contents

\begin{tabular}{|c|c|c|c|c|c|c|c|c|}
\hline $\begin{array}{c}\text { Degradation } \\
\text { temperature } \\
\left({ }^{\circ} \mathrm{C}\right)\end{array}$ & $\begin{array}{c}\text { Specific } \\
\text { gravity }^{a)}\end{array}$ & $\begin{array}{l}\text { Viscosity }^{b)} \\
(\mathrm{CST})\end{array}$ & $\underset{(\text { wto } \%)}{\text { Ash }}$ & $\begin{array}{l}\text { Conradson } \\
\text { carbon } \\
(\text { wto } \%)\end{array}$ & $\begin{array}{l}\text { Flash } \\
\text { point } \\
\left({ }^{\circ} \mathrm{C}\right)\end{array}$ & $\begin{array}{c}\text { Higher } \\
\text { calorific } \\
\text { value (cal } / g \text { ) }\end{array}$ & $\begin{array}{c}\text { Average } \\
\text { molecular } \\
\text { weight }\end{array}$ & $\begin{array}{c}\text { Iodine } \\
\text { number } \\
\left(\mathrm{g}-\mathrm{I}_{2} / 100 \mathrm{~g}\right.\end{array}$ \\
\hline \multicolumn{9}{|c|}{ Liquid products } \\
\hline 400 & 0.768 & 1.39 & 0.001 & 0.004 & $<25$ & 11130 & 181 & 82.3 \\
\hline 415 & 0.779 & 1.45 & $<0.001$ & 0.005 & $<25$ & 11150 & 185 & 87.5 \\
\hline 425 & 0.785 & 1.90 & $<0.001$ & 0.003 & $<25$ & 10890 & 201 & 85.3 \\
\hline 435 & 0.793 & 2. 40 & $<0.001$ & 0.005 & 28 & 10970 & 219 & 83.7 \\
\hline 445 & 0.799 & 3. 25 & $<0.001$ & 0.006 & 32 & 10890 & 232 & 83.5 \\
\hline \multicolumn{9}{|c|}{ Reactor contents } \\
\hline 400 & 0.867 & 122 & 0.053 & 0.24 & 296 & 11180 & 1150 & 12.8 \\
\hline 415 & 0.896 & 364 & 0.145 & 0.26 & 290 & 11130 & 1220 & 16. 9 \\
\hline 425 & 0.902 & 522 & 0.210 & 0.35 & 287 & 11140 & 1240 & 19. 2 \\
\hline 435 & 0.911 & 769 & 0.222 & 0.47 & 278 & 11150 & 1260 & 20.2 \\
\hline 445 & 0.918 & 727 & 0.313 & 0.82 & 281 & 10990 & 1260 & 21.8 \\
\hline
\end{tabular}

a) Liquid products at $150^{\circ} \mathrm{C}$, reactor contents at $25^{\circ} \mathrm{C}$.

b) Liquid products at $50^{\circ} \mathrm{C}$, reactor contents at $160^{\circ} \mathrm{C}$. 


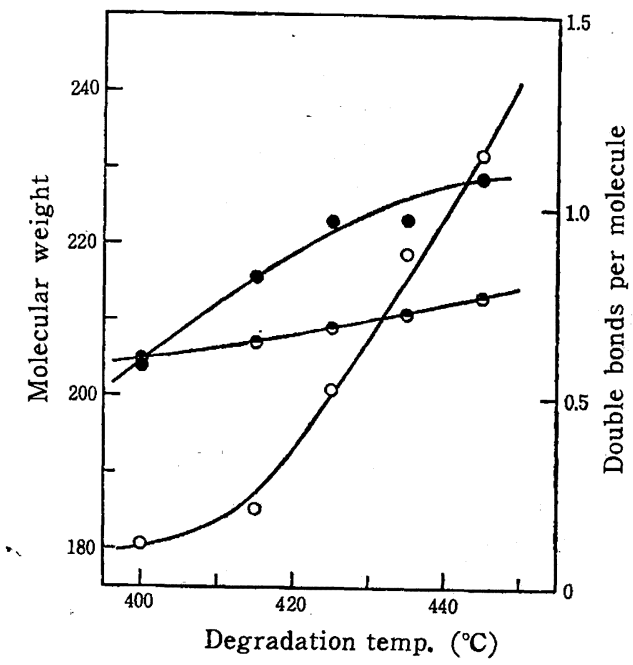

Fig. 9 Average molecular weight and double bonds per molecule

$O$ : Average molecular weight of liquid products

: Double bonds per molecule of liquid products

: Double bonds per molecule of reactor contents

分解油の諸性質の測定結果を表 3 に示す。室温 $20^{\circ} \mathrm{C}$ に扣ける 分解油の外観は分解温度 $400,415^{\circ} \mathrm{C}$ のbのは黄色味を帯びた透 明な液体であるが, 分解温度が $425^{\circ} \mathrm{C}$ になるとワックス状のる のが析出しどろどろした状態になる。さらに分解温度が上昇する と全体がワックス状に近くなり色す白味を増してくる。これは分 解油の分子量汇関係すると思われるが，分解油の平均分子量を分 解温度に対してプロットすると図9のよらな関係になり，分解温 度が高くなるにつれて平均分子量は急激に大きくなる。これは分 解温度の上昇は，上り大きな分子量の分解生成物を留出させる效 果があることによるるのと思われる。分解油は平均分子量のみを 比較すれば灯油に相当する油であるが，沸点範囲が広くガンリン 分, 軽油相当分も含まれる。また分解油には二重結合が多く含ま れ，ヨウ素価は実験範囲で 80 以上である。ヨウ素価と平均分子 量から計算すると分解油の分子のらち約 $60 \%$ 以上が二重結合を 1 個もっていることになるが，この割合は分解温度により巽なり 結果を図 9 に示す。

\section{4 管 液}

管液はポリエチレンが熱分解され分子量は原料よりかなり小さ くなっているが，まだガス状にはなれないで管内に滞留している あので, 常温では固体状で茶褐色または黒色であるが，分解温度 の管液を観察すると，さらさらして灯油が沸滕しているような状 態にある。管液の諸性質の測定結果を表 3 亿示す。表 3 には比重, 粘度, 灰分など分解油と同じ項目についての測定が示されている が，管液の比重は分解温度が高くなると大きくなる傾向が認めら れ，分解油より大きく，原料より小さい。粘度は管内でビスブレ 一キングされるため原料より大幅に小さくなっている。また灰分, 残留炭素は原料より大きくなっているが, 発熱量は原料, 管液, 分解油ともほぼ同じである。管液のヨウ素価は分解油と比較し小
さいが，1 分子あたりの二重結合は管液の方がむしろ大きい。こ のよ5すは図 9 に示した。管液の平均分子量は分解温度の上昇と ともに大きくなる傾向にあることなどが認められるが，分解油ほ どには顕著でない。管液の平均分子量は流入してくる新しいポリ マーと管内に以前から存在している古いポリマーとの動的な平衡 関係により決まるすのと思われる。また管液の平均分子量は原料 の約 $1 / 7$, 分解油の約 6 倍となっている。

以上の分解速度，分解生成物について述べてきたが，一般に高 分子化合物では C-C 結合が一つ破断すると二重結合一つを生成 すると考劣られて括り，たとえば Oakes らいは本実験より低い 温度 $\left(360^{\circ} \mathrm{C}\right)$ ではあるが，ポリエチレンの分解生成物 1 分子あた り約 1 個の二重結合をるっていると報告している。しかるに本実 験によれば, 分解油の 1 分子あたりの二重結合は $0: 6 \sim 0.75$ (図 9）であり，分解ガスでは 0.35 (表 2) に過ぎない。すなわち, 本実験における二重結合濃度は従来回分式の熱分解実験により得 られている濃度より小さくなっている。これは図 6,7および 8 に示されているよらに分解油の約 $50 \%$ が nーパラフィンである ことからす推測されるが，この理由についてはまだ確かめられて いない。

\section{4 結 言}

本報告では市販の高密度ポリエチレンの熱分解を原料を連続供 給できる実験装置を用いて行ない,その場合に得られる分解ガス， 分解油および管液の諸性質, 組成およびそれらの分解温度による 変化などについて述べた。ポリエチレンを熱分解して得られる分 解生成物は便宜的に常圧, 室温でガス状の分解ガスと夜状の分解 油にわけられるが, 分解留出量に占める分解油の割合は約 $94.5 \%$ であり, 分解温度 $400 \sim 445^{\circ} \mathrm{C}$ では分解温度による傾向はほとん ど認められなかった。分解ガスは $\mathrm{H}_{2}$ および $\mathrm{C}_{1} \sim \mathrm{C}_{5}$ の低級炭化 水素からなり, 平均分子量は $35 \sim 37$ である。分解油は $\mathrm{C}_{3} \sim \mathrm{C}_{30}$ の炭化水素の混合物で, n-パラフィン, 1-オレフィン, アイソマ 一が含まれるがその割合は分解温度により巽なる。たとえば分解 温度 $425^{\circ} \mathrm{C}$ では $n$-パラフィン, 1-オレフィン, アイソマーの割 合はそれぞれ 49.6，30.1，20.3\%であり，その平均分子量は 201 であった。また反応管内に滞留している管液は熱分解反応に 扣ける中間的生成物であるが，平均分子量約 1200 の固体状炭化 水素であり比重, 粘度, 分子量は原料より小さく, 分解油より大 きいが，灰分と残留炭素はもっとも大きい。管液のヨウ素価は分 解油のヨウ素価の $1 / 4$ 程度であるが， 1 分子あたりに含まれる二 重結合は管液の方が多いなどの結果を得た。

分解速度については分解生成物の留出量から求める分解留出速 度と C-C 結合の破断により生じる二重結合を定量して求める二 重結合生成速度の両方を測定し，温度に対しプロットした。実験 に用いられた高密度ポリエチレンの熱分解反応に括ける活性化エ ネルギーは，熱重量分析によれば $73 \mathrm{kcal} / \mathrm{mol}$ が得られたが，連 続式分解装置では分解留出速度から $47.5 \mathrm{kcal} / \mathrm{mol}$, 二重結合生 成速度から $49.4 \mathrm{kcal} / \mathrm{mol}$ が得られた。この違いは，連続式では 反応管中の気相部分が大きく，反応管の有効内容積が見かけ上小 さくなるためと考えられる。 


\title{
Thermal Degradation of High Density Polyethylene
}

\author{
Katsuhide Murata and Tadahiko Makino \\ Mitsui Shipbuilding \& Engineering Co., Chiba Lab. ; \\ Ichihara-shi 290 Japan
}

Thermal degradation experiment of high density polyethylene was carried out by using a continuous flow reactor in the temperature range of $400^{\circ}$ to $445^{\circ} \mathrm{C}$ under atmospheric pressure to investigate the rate of thermal degradation and properties of decomposition products at the steady state.

The products of thermal degradation were separated into two parts, the one, volatile gaseous product at $25^{\circ} \mathrm{C}$ and the other, less-volatile oily product. The gaseous product was analyzed by gas chromatography and was found to be consisted of $\mathrm{H}_{2}$ and $\mathrm{C}_{1} \sim \mathrm{C}_{6}$ hydrocarbons, having the average molecular weight of 35 to 37 . The composition of gaseous products did not change appreciably with the degradation temperature. The oily product was found to be consisted of a wide spectrum of hydrocarbon fragment, saturated and unsaturated, varying in carbon numbers from 3 to 30 (see Fig. 6,7). The average molecular weight of the oily product varied from 180 to 232 with degradation temperature (see Fig. 9). Other physical properties of oily products are shown in Table 3.

The average yield of product oil was $94.5 \%$ of the total products in the temperature range investigated. The reactor content was the degraded polymer and its molecular weight was decreased to about 1200 . Some physical properties of the reactor contents are shown in Table 3. The correlation between the rate of decomposition of the polyethylene and the rate of formation of double bonds, was also investigated. Both rates are plotted in Fig. 4 as a function of the degradation temperature. Carbon-carbon double bonds were found in gaseous products, oily product and reactor contents, but as shown in Fig. 5, the increase in double bonds of the reactor content was negligible. The activation energies of thermal degradation of the polyethylene, calculated on the basis of the above two rates, were $47.5 \mathrm{kcal} / \mathrm{mol}$ and $49.4 \mathrm{kcal} / \mathrm{mol}$, respectively. 